\title{
An assessment of the possibility of improving the ecological patency of the Bystrzyca river below Mietków in terms of increasing the capacity of the channel
}

\author{
Henryk Grzywna ${ }^{*}$, Radostaw Stodolak ${ }^{2}$ \\ ${ }^{1}$ Uniwersytet Przyrodniczy we Wrocławiu, Instytut Kształtowania i Ochrony Środowiska, \\ pl. Grunwaldzki 24, 50-363 Wrocław \\ ${ }^{2}$ Uniwersytet Przyrodniczy we Wrocławiu, Instytut Inżynierii Środowiska, \\ pl. Grunwaldzki 24, 50-363 Wrocław
}

\begin{abstract}
The work contains an assessment of the possibility of improving the ecological patency of the river in terms of increasing the capacity of the channel. It is based on the analysis of the correction of the riverbed capacity by improving and optimizing the damming structure operation. The damming structures located in the riverbed have a negative impact on the aquatic environment and they have crossed the ecological corridors which are natural migration routes for fish. For the purpose of improving the ecological patency, a one-dimensional hydraulic model was built in the HEC-RAS program. Using stationary flow module, water table in each of the tested cross-sections was calculated. The model was used to build a module for optimizing gates of damming structure. Following the results, such a system variant of damming structure operation was proposed on the Bystrzyca river section to obtain the highest possible patency of the section and provide optimal conditions for fish migration. The study shows the relation between the hydraulic capacity of the watercourse and the ecological patency. It is also shown that these parameters depend on each other and an increase in the hydraulic capacity improves the ecological patency of the rivers.
\end{abstract}

\section{Introduction}

The capacity of a stream is understood as such a state that allows free flow of water, ice and other materials carried by a river [1-3]. Streams are ecological corridors and are one of the most important places for living and reproduction of organisms. Damming structures adversely affect the patency of watercourses and they are also barriers disrupting migration and ecological corridors. These kinds of objects cause both an interruption of the ecosystem continuum and also change in physical, chemical and biological conditions of the watercourse. Due to the increase of accumulation and erosion of the material in the river channel, they also change the hydrological regime [4].

\footnotetext{
*Corresponding author: henryk.grzywna@upwr.edu.pl
} 
The impact of the damming structures on change in ecosystem is often so large that the displacement of some species occurs and their place is taken by new ones which are better adapted to the new conditions in watercourse $[5,6]$. In addition, such construction in the watercourse affects the flood risk [7].

The UE Member States were obliged to assess the condition of groundwater and surface waters. One of the used methods was developed by Deutscher Verband für Wasserwirtschaft und Kulturbau (DVWK) in 1984 [8], then modified by Ilnicki and Lewandowski [9]. It focuses on the assessment of four parameters: stream, bank and terrestrial biotope and ecological capacity. The evaluation of the ecological patency of the section is also based on the determination of fish species that are important for maintaining the morphological continuum of ecological corridors [10, 11].

The mathematical model of a river is a mathematical generation that links variables describing the initial conditions (state of the object), boundary conditions (external impact of the object) and the reaction of the object to external impacts $[12,13]$. HEC-RAS is a program created by US Corps of Engineers. It has a built-in stationary flow module which allows to calculate the position of the water table in the cross section. Energy equations and the amount of motion equations serve as the basic equations used by the numerical HEC-RAS model [14]. The program makes it possible to calculate energy losses in the cross section and in the whole range filling [23]. The engine of the model allows accurate representation of the flow including all elements of the hydraulic structures like: levees, weirs and stages, high and low bridges and culverts [23]. The equations used for the calculation of overflow allow for simultaneous modeling of partitions as well as different kinds of gates including, among others, fixed, movable, segmental, gate, flap and sector ones $[14,15]$.

The aim of the work was to create a model allowing for such optimized use of hydraulic structure which will increase riverbed capacity and improve the ecological patency of the river. The operation of the damming devices was analyzed in the work and such methods of opening the gates were proposed to achieve the greatest possible capacity of the river section, while maintaining their function.

\section{Methodology}

\subsection{Research area}

The Bystrzyca river is a left-bank tributary of the Odra river which joins the Odra river in Wrocław. There are two reservoirs created on the river: the Lubachów reservoir in Zagórze Śląskie and the Mietków reservoir. The total area of the Bystrzyca catchment is $1779.95 \mathrm{~km}^{2}$ (figure 1) [16]. The Bystrzyca section, which is the subject of the study, is approximately $31.5 \mathrm{~km}$ long. The barrage of the Mietków reservoir at kilometer $45+030$ was considered as the initial cross-section, while the Jarnołtów gauge section at kilometer $13+520$ constitutes the end of the research section. The Bystrzyca river in this section is controlled by two water gauges belonging to IMGW-PIB.

\subsection{Field inventory}

Field ecological inventory is a key element of the decision making process in water management. Without a detailed diagnosis of the current state of the object, it is impossible to make attempts to indicate recommendations, prepare concepts or start proper design.

For the needs of this research, an inventory for all of the hydraulic structures was made on the Bystrzyca section between Mietków reservoir $(56+030 \mathrm{~km})$ and Jarnołtów gauge 
$(13+520 \mathrm{~km})$. The inventory included all damming constructions: weirs, stages, bridges and footbridges. On the basis of the data collected during the inventory, the parameters and types of gates of hydrotechnical objects were determined. Their function was determined and such objects were selected which are not used anymore or/and do not fulfill their function.

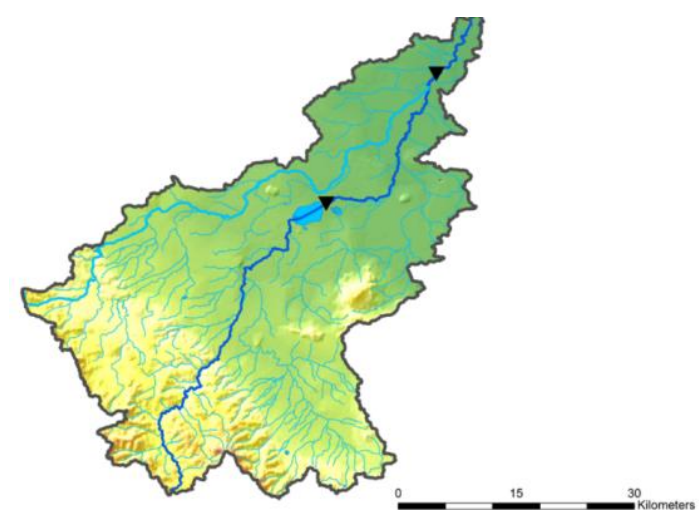

Fig. 1. Topography of the Bystrzyca river catchment with a study river section and computational cross-sections of the dam in Mietków and the Jarnołtów water gauge (own elaboration PUWG-92).

\subsection{Species of fish present in the channel}

The species composition of the Bystrzyca river's ichthyofauna is represented by 17 species. The section between Mietków and Jarnołtów can be classified as the barbell land [1, 4]. At the same time it is important to mention the occurrence of bi-environmental fish such as Salmon (Salmo salar) which is present in both the Bystrzyca channel and Strzegomka, its tributary [11]. The regulation established by the Director of Wrocław Water Management Authority contains fish species important for maintaining the morphological continuity of ecological corridors [10]. According to this regulation, salmon represents the species of fish appropriate for the ecological corridor of the Bystrzyca river. The analysis of the restoration of the ecological patency of the investigated section was conducted on the basis of the habitat of this species.

\subsection{Assessment of ecological patency of the section}

The ecological patency of the river was defined as its accessibility for water fauna, perceived as a continuous system in which organisms should be able to move freely up and down the watercourse $[3,17]$. The barrier on the river is a technical, behavioral or natural obstacle in the watercourse which, due to its height, structure, hydrological, morphological or physicochemical properties, water organisms cannot overcome migrating up or down the watercourse $[6,18,19]$. The evaluation of patency of the study river section focused on two aspects 1) the possibility of migration of salmon as a species proper to the Bystrzyca ecological corridor, 2) the possibilities of migration of smaller species. Migrating salmon are able to jump over barrier between $1.0 \mathrm{~m}$ and $1.7 \mathrm{~m}$ high [2]. However, according to the FAO recommendations, it was determined that the maximum height of hydraulic structure that can be overcome by fish can range from 10 to $30 \mathrm{~cm}$ depending on the species composition of migrating fish [1]. Table 1 includes analyses of ecological patency of hydraulic structures in the study area. They were divided into two groups: with a river 
bar above $1.0 \mathrm{~m}$ - a barrier to overcome by salmon and below $1.0 \mathrm{~m}$ - possible to overcome by salmon, difficult to overcome by smaller species.

Table 1. Assessment of ecological patency based on height of the river bar or weir in the study area.

\begin{tabular}{|c|c|}
\hline height of structure $0.3 \mathrm{~m}<<\mathrm{h}<1 \mathrm{~m}$ & height of structure $\mathrm{h}>1 \mathrm{~m}$ \\
\hline Mietków river bar & Kamionna - Okulice weir \\
\hline Jarnołtów river bar I & Kąty Wrocławskie weir \\
\hline Jarnołtów river bar II & Jurczyce weir \\
\hline & Sadowice weir \\
\hline & Skałka weir \\
\hline & Samotwór weir \\
\hline
\end{tabular}

The assessment of the possibility of overcoming the hydraulic drop of hydrotechnical objects was used to assess the patency of the watercourse sections. It was assumed that the section located below the given facility has the same ecological patency as the cross-section of the object at the beginning of this section. This is conditioned by the fact that the damming objects are the main barriers which are responsible for the intersection of the ecological corridor in river beds [20].

\subsection{Hydraulic model}

Guaranteeing the required capacity of inlet and bleed devices and ensuring proper use of these devices is one of the ways to ensure the safety of damming constructions [7]. From a hydraulic point of view, a weir or a dam in a river channel is treated as a spillway that is a part of a dam inserted into a stream with free water level which the water overflows $[21,22]$. The main aspects related to the calculation of the capacity of the facility are the basic parameters of the water flow: the height of the hydraulic structure, the height of the water layer overflowing through the structure and the width of the hydraulic structure corresponding of the cross-section area [23, 24].

The analysis of the capacity of nine damming objects located in the study area was carried out using the program HEC-RAS 4.1.0 based on the one-dimensional hydraulic model. Objects in the forms of flow or weirs are modeled as spillway crests of practical shape [14]. HEC-RAS calculates the position of the water level in cross-sections, hence it is necessary to introduce a complete geometry of the watercourse into the model, which should represent the shape of the river network and cross-sections. The calculations performed by the model are based on the Chezy formula in the form of Manning-Chezy equation 1. This formula helps to calculate elevations of head loss for neighbouring cross-sections equation 2 .

$$
v=\frac{1}{n} \cdot R_{h}^{\frac{2}{3}} \cdot \sqrt{I}\left[m \cdot s^{-1}\right]
$$

Eq. 1. Chezy formula $\left(\mathrm{R}_{\mathrm{h}}-\right.$ the Hydraulic Radius, $R_{k}=\frac{\varepsilon}{v}[\mathrm{~m}]$, A - the cross sectional area of flow $\left[\mathrm{m}^{2}\right], \mathrm{U}-$ the wetted perimeter $[\mathrm{m}], \mathrm{n}-$ Manning's coefficient $\left[m-\frac{1}{3} \cdot s\right], \mathrm{I}-$ the linear hydraulic head loss [-]).

$$
Z_{2}+Y_{2}+\frac{\alpha_{2}+v_{2}^{2}}{2 g}=Z_{1}+Y_{1}+\frac{\alpha_{1}+v_{1}^{2}}{2 g}+h_{B}
$$

Eq. 2. Energy conservation formula $\left(Z_{2}, Z_{1}\right.$ - the elevations of channel depth $[\mathrm{m}], \mathrm{Y}_{2}, \mathrm{Y}_{1}$ - the water depth of cross sections 1 and $2[\mathrm{~m}], \alpha$ - the velocity weighting coefficients [-], $\mathrm{v}_{1}, \mathrm{v}_{2}-$ the average velocities $\left[\frac{m}{s}\right], g-$ the gravitational acceleration $\left[\frac{m}{g^{2}}\right]$, he - the energy head loss $[\mathrm{m}]$ ). 
In order to determine the initial position of the water table, it is necessary to determine the boundary conditions in the extreme cross-sections of the model - in the lower one for calm flows and in the upper one for the rapid flows $[6,25]$. The boundary condition introduced into the model is the flow rate curve for the Mietków water gauge.

The basic assumption of the simulations performed using a hydraulic model is the assumption that the flow in the channel is a steady flow $[15,26]$. This theory was proposed by Saint-Venant and is based on the following theses: the flow is one-dimensional; the speed components in a direction other than perpendicular to the direction of movement are negligible; y-coordinate of the energy line is the same in the entire cross-section; pressure distribution in the cross-section is hydrostatic, the flow is of slowly varying character; velocity distribution in the vertical is uniform [27].

The calibration of the model was done by comparing the characteristic observed and calculated ordinates obtained in the simulation results. The calibration was performed for the following values of characteristic and probable flows determined basing on the years 1951-2010: SNQ, SSQ, SWQ, WWQ, Q ${ }_{10 \%}, \mathrm{Q}_{1 \%}, \mathrm{Q}_{0,2} \%$. The correlation coefficient obtained for the first and last cross-section in the model, section in Mietków and the Jarnołtów water gauge, showed a large statistical determination of around 0.9.

\subsection{Module of optimizing gates of damming structure}

The module of optimizing gates of damming structure consists of series of simulations carried out in the following variants: 1) full gates opening, 2) closing the gates/valves, 3) half gates opening, 4) incomplete opening of the gate valve. In the case of multi-span structure, the individual scenarios included a combination of the number of active spans, individually for each damming object. The analyses focused on checking the response of individual objects to medium and low flows. Characteristic flows were used for modeling such as SWQ, Q50\%, SSQ, SNQ and NNQ. For each of the simulation variants, the size of the hydraulic drop was determined. Such objects were selected whose hydraulic drop is greater than $1,0 \mathrm{~m}$. This height of hydraulic drop causes the discontinuation of the ecological patency restricting the migration of the salmon. The next stage was to determine the conditions in the river after eliminating the structure which was considered unnecessary or/and its demolition was taken into consideration. In this way, a simulation variant 5 was obtained where water energy table and energy lines in the longitudinal profile of the river channel were taken into account after removing objects.

\section{Results}

The comprehensive inventory and the valorization of ecohydrological and hydromorphological factors constituted the first stage of the analysis of the possibility of restoring ecological patency in the studied section of the Bystrzyca river. The inventory showed a low ecological patency of the section for the most of the structures, which is mainly due to the heights of damming since it is impossible for fish to overcome them (figure 2).

The hydraulic model of the test section, including module of optimizing gates of damming structures allowed to determine such a way of working of damming hydraulic structures, that while maintaining their function, the ecological patency of the Bystrzeca river below the Mietków reservoir increases and thus it enables fish migration. However, it was assessed that, despite increasing the patency, total continuity would not be restored. The degree and method of opening gates of damming structure affect the change of such parameters as hydraulic drop. The damming structures under the study have such a height of damming that it is impossible to open the gates in such a way that the patency 
of the tested river section can be fully restored. Figure 3 shows the patency of the analyzed objects. They were classified as structures with full patency, non-patency and partially patency. The latter are those that allow the migration of fish only under certain hydrological conditions in the river.

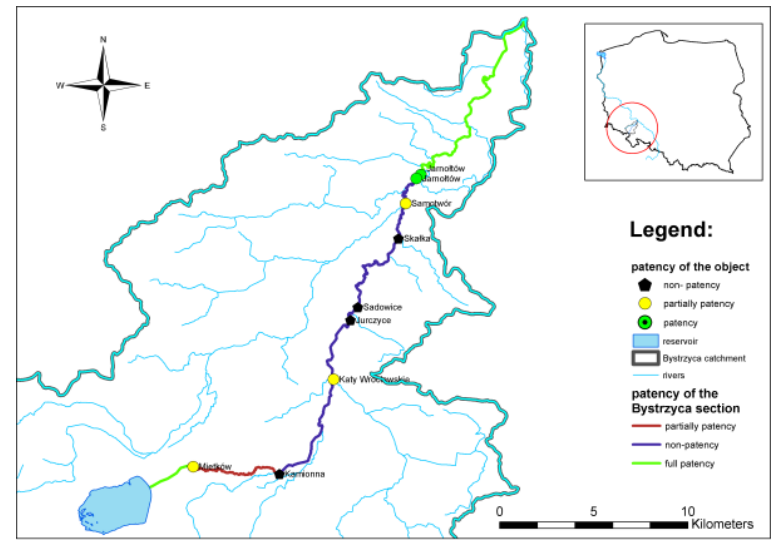

Fig 2. Result of inventory and valorization of ecohydrological and hydromorphological factors in the study area. Assessment of the ecological patency of the hydraulic structure in the studied section (own elaboration PUWG-92).

The results of the simulation show that the Bystrzyca river in the section from the reservoir in Mietków has good ecological patency along the section of approx. $16.5 \mathrm{~km}$, from the estuary to the Samotwór weir $(\mathrm{km} 16+382)$. The section from the weir in Samotworze $(\mathrm{km} 16+382)$ to the Sadowice weir $(\mathrm{km} 24+708)$ is still classified as non-patency. From the Sadowice weir $(\mathrm{km} 24+708)$ to the Kąty Wrocławskie weir $(29+951)$, the riverbed remains patent in the presence of medium flows. Kamionna - Okulice weir $(\mathrm{km} 36+848)$ is a barrier for migration of fish, hence the section from the Kąty Wrocławskie weir $(29+951)$ to the Kamionna - Okulice weir $(\mathrm{km} 36+848)$ is characterized as ecologically obstructed. From the Kamionna - Okulice weir $(\mathrm{km} 36+848)$ to the barrier in Mietków, the Bystrzyca river has full ecological patency when appearing in the medium flows.

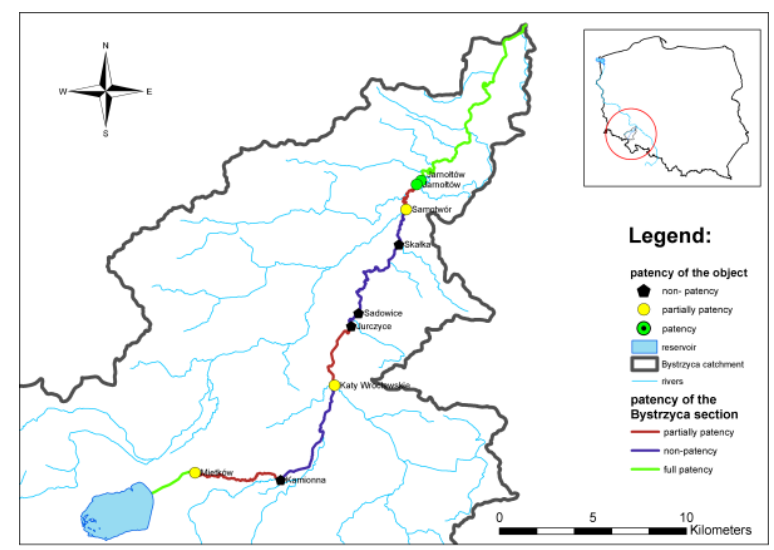

Fig.3. The results of the model of optimizing gates of damming structures. Phases 1-4, evaluation of the ecological patency of hydraulic structures. 
After removing the non-functional weirs Kamionna-Okulice and Jurczyce, the patency of the section from the dam of the reservoir in Mietków to the weir in Sadowice $(\mathrm{km} 24+708)$ has improved, which is determined only by the flow conditions prevailing in the riverbed. This is related to the fact that the weir in Mietków and the Kąty Wrocławskie weir are not available for fish migration in the case of low flows. The ecological patency of the river section to Sadowice weir is conditioned by the size of the water discharges from the reservoir in Mietków (Figure 4).

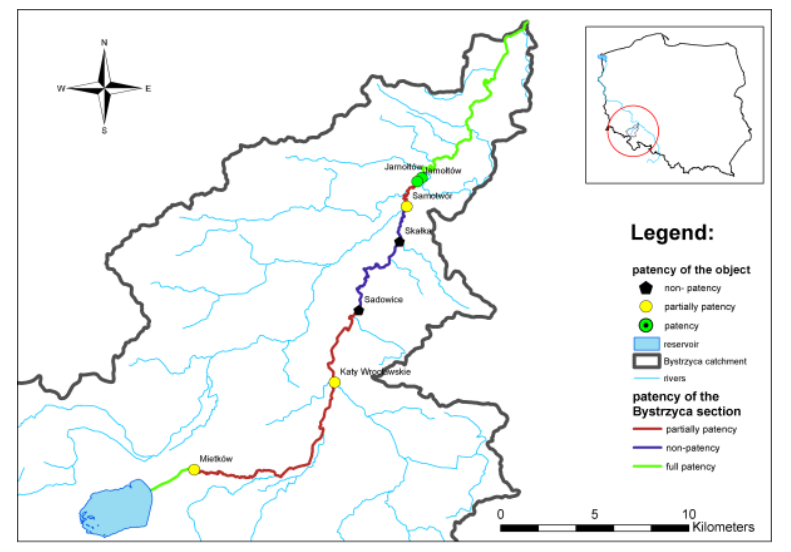

Fig.4. The result of the model of optimizing gates of damming structure. Phase 5 removing of non-functional objects.

\section{Conclusion}

The propose module of optimizing gates of damming structure is a way to increase the ecological patency of the river. The proposed approach is definitely less expensive from an engineering point of view to solve the problem of the need to ensure fish migration. The study shows the relation between slight changes in the opening of damming structure gates and the change in water conditions in the watercourse, in particular the height of damming and water velocity. This is especially noticeable in the case of sections where the application of the proposed module procedures caused the restoration of ecological patency. Such positive effects are observed in the sections from the Sadowice weir $(\mathrm{km} 24+708)$ to the Kąty Wrocławskie weir $(29+951)$ and from the Kamionna - Okulice weir $(\mathrm{km} 36+848)$ to Mietków dam. The total length of sections on which ecological patency has been restored is $11,01 \mathrm{~km}$, which is $24 \%$ length of the studied Bystrzyca section. Incomplete effectiveness of the designed module may result from the fact that the ecological patency is very bad in the section from the Mietków reservoir to the Jarnołtów water gauge. The damming structures located there often come from the times before World War II, when the approach related to ensuring free migration of fish was not applied. Therefore, the use of the optimization module itself turned out to be insufficient. Nevertheless, the study shows that it is possible to optimize the operation of a damming structure and that after skipping significant investment outlays e.g. fish ladder, it is possible to restore the ecological corridor, and thus allow the migration of aquatic organisms. 


\section{References}

1. Błachuta J., et al. The National Fund for Environmental Protection and Water Management (NFEP\&WM) (2012)

2. Bojarski A., Jeleński J., Jelonek M., Litewka T., Wyżga B., Zalewski J. Warsaw: Ministry of the Environment (2005)

3. Jędryka E. Woda-Środowisko-Obszary Wiejskie, 39-56 (2009)

4. Szymanowski Z. i inni. Wrocław: Water Service (2002)

5. Bonisławska M. Gospodarka Wodna, 1, 34-43 (2010)

6. Jones J., Stanley E., Stream Ecosystems in a Changing Environment (2016)

7. Michalec B., Tarnawski M. Infrastruktura i Ekologia Terenów Wiejskich, IV 65-76 (2012)

8. DVWK. Ökologische Aspecte bei Ausbau und Unterhaltung DVWK-Markblatter 204/1984. Deutscher Verband für Wasserwirtschaft und Kulturbau (1984)

9. Ilnicki P. i inni. Woda-Środowisko-Obszary Wiejskie, XI, 97-112 (2011)

10. Rozporzadzenie Dyrektora Regionalnego Zarzadu Gospodarki Wodnej we Wrocławiu w sprawie ustalenia warunków korzystania z wód regionu wodnego Środkowej Odry. (RZGW we Wrocławiu, 31 maj 2013).

11. Wiśniewolski H. Piaseczno: ICHT-LOG rybactwo i inne (2010)

12. Mohd T.A.,Abdullah K.,.Nawawi M.N.M., Nik Norulaini NikAb Rahman., Abd. Rahni Mt.Piah., Nor Azaz Zakari., M.I.Syakir., A.K. Mohd. Omarb., Journal of African Earth Science, 124, 478-486 (2016)

13. Siwek G. Kraków: Uniwersytet Pedagogiczny w Krakowie (2013)

14. Brunner G. HEC-RAS, River Analysis System Hydraulic Reference Manual (2002)

15. Brunner, G.W. HEC-RAS River Analysis System. Hydraulic Reference Manual (1995)

16. Staff M., Stownik geografii turystycznej Sudetów (1994)

17. Rodriguez-Iturbe I., Muneepeerakul R., Bertuzzo E., Levin S., Rinaldo A., Water Resources Research, 45, 1 (2009)

18. Rinaldo A,, Gatto M., Rodriquez-Iturbe I., Adv Water Resour, 122, $27-58$ (2018)

19. Radinger J., Holker F., Horky P., Slavij O., Wolter W., J Environ Manage, 208, 169179 (2018)

20. Wierzbicki M. Landform Analysis, IV, 107-113 (2013)

21. Khatsuria M. Hydraulics of Spillways and Energy Dissipaters (2006)

22. Sobota J., Hydraulika i Mechnika Płynów. Wrocław (2003)

23. Deal E., Dawid Parr A., Young B., A Comparision Study on One- and TwoDimensional Hydraulic Models of River Environments. Final Raport (2017)

24. Chiogna G, Majone B., Paoli Cano K., Diamantini E., Stella E., Mallucci S., Lencioni V., Zandonai F., Bellin A., Sci Total Environ 540, 429 (2016)

25. Pasiok R. Instytut Badawczo-Rozwojowy "PPC" Sp. z o.o. (2008).

26. Niraj L., Suresh S., Hydrology, 24, 4 (2) (2017)

27. Artichowicz W. Modelowanie przeptywu ustalonego niejednostajnego w kanałach otwartych. Praca Dokorska. Gdańsk (2012) 